\title{
Pengaruh Ekstrak Daun Belimbing Wuluh Terhadap Histamin Pada Ikan Cakalang (Katsuwonus pelamis) ASAP
}

\section{The Effect of Wolf Wing Leaf Extract On Histamin In Cakalang Fish (Katsuwonus pelamis) Smoke}

\author{
Ida Astuti ${ }^{1}$ dan Asniati Ningsi² \\ 1-2 Program Studi Perikanan dan Kelautan Universitas Gorontalo. \\ E-mail : $\underline{\text { badariadgkanang@gmail.com }}$
}

\begin{abstract}
Abstrak
Histamin merupakan senyawa turunan dari asam amino histidin yang banyak terdapat pada ikan. Asam amino ini merupakan salah satu dari sepuluh asam amino esensial yang dibutuhkan oleh anak-anak dan bayi tetapi bukan asam amino essensial bagi orang dewasa. Histamin akan berbahaya jika seseorang mengonsumsi ikan dengan kandungan histamin $50 \mathrm{mg} / 100 \mathrm{~g}$ daging ikan. Tujuan dari Penelitian ini adalah untuk mengetahui pengaruh ekstrak daun belimbing wuluh terhadap histamin selama penyimpanan. Metode yang digunakan adalah metode eksperimen dengan menggunakan konsentrasi 0 sebagai control dan $10 \%$ sebagai perlakuan ekstrak dengan lama penympanan 4 hari dengan 3 kali ulangan. Rancangan yang digunakan adalah rancangan acak lengkap. Berdasarkan hasil pengujian histamin pada semua perlakuan didapatkan hasil kandungan histamin berkisar antara $33,02-48,58 \mathrm{mg} / 100 \mathrm{~g}$. Kandungan histamin pada ikan cakalang fufu masih memenuhi Standar Nasional Indonesia (SNI) ikan asap yaitu maksimum $100 \mathrm{mg} / 100 \mathrm{~g}$.
\end{abstract}

Kata Kunci: Histamin, Ikan asap, daun belimbing, ekstrak, Cakalang.

\section{Abstract}

Histamine is a derivative of histidine amino acids which is widely found in fish. This amino acid is one of the ten essential amino acids needed by children and infants but not essential amino acids for adults. Histamine will be dangerous if someone eats fish with $50 \mathrm{mg}$ of histamine / $100 \mathrm{~g}$ of fish meat. The purpose of this study was to determine the effect of wuluh starfruit leaf extract on histamine during storage. The method used is an experimental method using 0 concentrations as a control and $10 \%$ as an extract treatment with 4 days of storage with 3 replications. The design used is a completely randomized design. Based on the results of histamine testing in all treatments the results of histamine content ranged between $33.02-48.58 \mathrm{mg} / 100 \mathrm{~g}$. The histamine content of fufu skipjack fish still meets the Indonesian National Standard (SNI) for smoked fish, which is a maximum of $100 \mathrm{mg} / 100 \mathrm{~g}$.

Keyword: Histamine, smoked fish, starfruit leaves, extract, Skipjack. 


\section{PENDAHULUAN}

Hasil produksi ikan cakalang di provinsi Gorontalo mencapai 4.979 ton sedangkan ikan tongkol mencapai 4.086 ton (DKP Gorontalo, 2015). Hal ini setara dengan Rp. 319 milliar dari capaian produksi total yaitu Rp.23.563 ton. Sedangkan menurut badan Pusat Statistik Kabupaten Gorontalo Utara menyatakan bahwa pada tahun 2016 hasil produksi tangkapan ikan cakalang mencapai 4.000 ton. Ikan cakalang ini tidak semuanya dikirim ke Manado serta kabupaten lainnya, tetapi masyarakat telah mengolahnya menjadi olahan yang yang bernilai ekonomis, seperti abon ikan, panada dan ikan cakalang asap (fufu).

Ikan fufu adalah hasil pengawetan ikan secara tradisional yang pengerjaannya merupakan gabungan dari penggaraman (perendaman dalam air garam) dan pengasapan sehingga memberikan rasa khas. Untuk mengetahui mutu produk ikan yang aman dikonsumsi perlu dilakukan pengujian mutu seperti uji kadar histamin, TVB dan angka peroksida. Pengujian histamin bertujuan untuk mengetahui kandungan racun yang terdapat pada ikan cakalang. Kadar histamin atau racun yang terdapat dalam produk pangan dapat mengakibatkan sakit kepala, muntah-muntah, alergi bahkan dapat menyebabkan kematian. Oleh karenanya histamin penting untuk diketahui demi keamanan pangan. Begitupun kandungan senyawa basa volatil yang terbentuk akibat degradasi protein serta bilangan peroksida pada ikan cakalang. Keberadaan senyawa peroksida juga digunakan sebagai indikator terjadinya oksidasi lemak dan tingkat kerusakan lemak. Semakin tinggi bilangan peroksida maka semakin tinggi pula tingkat kerusakan lemak

Beberapa penelitian telah dilakukan dalam menghambat bakteri. Misalnya, penggunaan bahan pengawet dari tanaman, seperti daun sirih, daun jambu biji dan daun teh hijau. Selain itu, ada beberapa tanaman yang memiliki senyawa yang juga diduga dapat menghambat aktifitas bakteri. Misalnya, belimbing wuluh mengandung zat yang dapat membunuh bakteri pada ikan cakalang segar dengan lama penyimpanan 6 - 8 jam (Astuti, 2014). 


\section{METODE PENELITIAN}

\section{Waktu Dan Tempat}

Penelitian dilakukan pada bulan Maret - Mei 2018, bertempat di Laboratorium Fakultas Pertanian Universitas Gorontalo dan dianalisis di Povincial Laboratory and Quality Development of Marine and Fisheriae Produck, Makassar.

\section{Alat Dan Bahan}

Alat yang digunakan untuk analisis histamin dengan Spektrofluorometri adalah labu erlenmeyer, gelas ukur, pisau, blender, waterbath, labu ukur, kertas saring Whattmann, spektrofluorometer tipe Varian Cary Eclipse FL0811M007, glass wool, pipet volumetrik, pipet tetes, dan timbangan analitik dan buret. Bahan yang digunakan dalam penelitian ini adalah ikan cakalang (Katsuwonus pelamis) fufu yang diambil dari Unit Pengolahan ikan di Kab, Gorontalo, daun Belimbing Wuluh (Averhoa billimbi), etanol, resin penukar ion (dowex 1-x800-100-mesh), dan aquades serta bahan - bahan untuk mengukur histamin.

\section{Prosedur Penelitian}

1. Daun Belimbing

Daun Belimbing Wuluh (Averrhoa bilimbi) yang didapatkan dari kebun penduduk yang terdapat di kabupaten Gorontalo. Daun ini dipisahkan dari tangkainya dan dikeringkan dengan oven pada suhu $40-50^{\circ} \mathrm{C}$ atau dengan pengeringan di bawah sinar matahari selama 2 hari, kemudian digiling dengan hingga halus dan diayak dengan ayakan 25-35 mesh. Proses penggilingan daun dapat mempengaruhi ekstraksi. Menurut Ketaren et.al. (1994), daya ekstraksi semakin meningkat dengan semakin kecilnya ukuran bahan, karena kontak antara bahan dan pelarut merupakan proses osmosis yang berjalan lambat.

2. Ekstraksi Daun Wuluh

Ekstraksi adalah proses pemisahan, penarikan atau pengeluaran suatu komponen campuran dari campurannya. Biasanya menggunakan pelarut yang sesuai dengan komponen yang diinginkan, cairan dipisahkan dan diuapkan sampai pada kepekatan tertentu (Manan, 2008 dalam Mukhliso, 2010).

Serbuk daun diekstraksi menggunakan metode maserasi dengan perbandingan bahan dan pelarut (Alkohol 70\%) $1: 7$. Kemudian direndam 
selama 24 - 48 jam dan diaduk setiap 2 jam. Pengadukan bertujuan untuk mempercepat bahan terekstraksi. Filtrat hasil penyaringan diuapkan sampai dihasilkan ekstrak kental.

3. Perendaman ikan

Ikan yang telah diambil dari UPI dibawa ke Laboratorium dan selanjutnya direndam dengan ekstrak daun belimbing wuluh. Sebelum ikan direndam, terlabih dahulu Ekstrak dicampurkan dengan aquades sampai mencapai konsentrasi 10\% untuk perlakuan B0 dan B4, Sedangkan perlakuan A sebagai control atau tanpa ekstrak. Ikan yang telah direndam kemudian ditiriskan dan disimpan selama 4 hari pada suhu ruang lalu dilakukan pengujian.

\section{Pengujian Sampel Penelitian}

Analisis kadar histamin mengacu pada SNI 2354.10: 2009 dengan Prinsip penentuan histamin adalah zat histamin dalam contoh dikonversikan ke dalam bentuk-OH, kemudian diisolasi dengan resin penukar ion dan diubah ke bentuk derivatnya dengan ortoptalat dikarboksilaldehide (OPT) dan diukur secara fluorometris. Hasil yang diperoleh dinyatakan dalam ekuivalen histamine.

Sebanyak $10 \mathrm{ml} \mathrm{HCl} \mathrm{0,1} \mathrm{N} \mathrm{dipipet} \mathrm{dan} \mathrm{dimasukkan} \mathrm{ke} \mathrm{dalam} \mathrm{tabung} \mathrm{reaksi}$ kemudian ditambahkan $5 \mathrm{ml}$ sampel hasil tahap celan up/elusi, $5 \mathrm{ml}$ histamin standar (sebagai larutan standar), dan $5 \mathrm{ml} \mathrm{HCl} \mathrm{0,1} \mathrm{N} \mathrm{(sebagai} \mathrm{blanko).} \mathrm{Setelah}$ itu, ditambahkan $3 \mathrm{ml} \mathrm{NaOH} 1 \mathrm{~N}$ ke dalam tabung reaksi lalu di homogenkan dan dibiarkan selama 5 menit. Selnjutnya ditambahkan lagi Ortoptalatdikarboksilalde hide (OPT) $1 \%$ sebanyak $1 \mathrm{ml}$ lalu dihomogenkan dan didiamkan selama 4 menit. Selanjutnya ditambahkan $3 \mathrm{ml} \mathrm{H}_{3} \mathrm{PO}_{4} 3.57 \mathrm{~N}$ dan dihomogenkan. Setelah selesai, sampel yang telah melalui tahap pembentukan siap untuk dibaca menggunakan spektrofluorometer pada panjang gelombang eksitasi $350 \mathrm{~nm}$ dan panjang gelombang emisi $444 \mathrm{~nm}$. Rumus perhitungan histamin (ppm) adalah sebagai berikut:

$$
\operatorname{Histamin}(\text { ppm })=\frac{\frac{I U \text { Sampel }-A}{B} \times F P}{\text { Bobot Sampel }(g)}
$$

Keterangan:

$$
\mathrm{IU}=\text { Absorban sampel } A=\text { Intersep }
$$




$$
B=\text { Slope } \quad F p=\text { Faktor pengencer }
$$

\section{HASIL DAN PEMBAHASAN}

\section{Histamin}

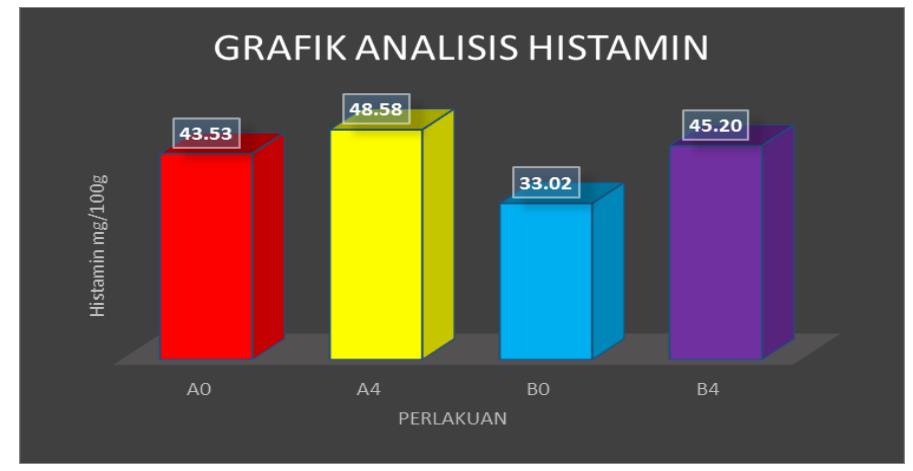

Sumber: Olahan Data Primer 2018

Gambar 1. Kandungan Histamin Ikan Cakalang

Kadar histamin pada produk ikan Cakalang (Katsuwonus pelamis) asap dengan perlakuan AO (tanpa ekstrak) lebih tinggi dibandingkan dengan perlakuan B0 (perendaman ekstrak) tanpa penyimpanan. Perlakuan A4 dan B4 dengan menggunakan ekstrak daun belimbing wuluh juga memiliki kadar histamin yang berbeda. Pada perlakuan A4 memiliki kadar histamin yang lebih tinggi dibandingkan dengan B4. Hal ini kemungkinan dipengaruhi oleh lama penyimpan yang kurang baik. Astuti, et.al (2015) menyatakan bahwa histamin pada ikan cakalang yang direndam dengan menggunakan ekstrak daun belimbing menunjukkan hasil yang cenderung meningkat seiring dengan lamanya penyimpanan. Selain itu, ini juga dipengaruhi oleh kondisi ikan yang belum kering sempurna lalu dikemas sehingga uap air dari daging ikan tertahan oleh plastik sampel. Dengan demikian ikan sampel mengandung kadar air yang tinggi sebagai media yang baik untuk pertumbuhan bakteri. Tingginya kandungan histamin ditiap bagian daging ikan dipengaruhi oleh jumlah bakteri penghasil histidin dekarboksilase (Kung et al.,2009). Peningkatan kadar histamin yang pesat merupakan akibat dari pertumbuhan bakteri penghasil histamin yang optimum (Kanki et al., 2007).

Akan tetapi jika kita melihat peningkatan histamine pada setiap perlakuan tidak jauh berbeda, walaupun ada peningkatan pada perlakuan penyimpanan selama 4 hari. Pada ekstrak daun belimbing wuluh terdapat 
senyawa flavonoid, saponin, terpenoid dan tanin yang mampu mencegah pertumbuhan bakteri (Kamilah et.al.,2010).

Dengan adanya senyawa tersebut maka perombakan protein dan juga lemak oleh bakteri dapat ditekan. Akibatnya, pembusukan pada ikan yang akan meningkatkan nilai kadar histamine terhambat. Menurut Nento et al, (2014) penanganan adalah kunci utama dalam menghambat terbentuknya histamin, perubahan warna, kelarutan protein, dan pertumbuhan mikroba pada ikan Cakalang (Katsuwonus pelamis). Pengasapan ikan dimaksudkan untuk mempertahankan kesegaran, dalam arti masih memenuhi syarat untuk bisa dikonsumsi dengan jalan menghambat terjadinya pembusukan ikan. Pengasapan ikan merupakan salah satu metode pengolahan ikan yang mengkombinasikan proses penggaraman, pemanasan dan pelekatan komponen kimiawi asap (Wibowo, 2000). Selain itu penurunan kadar histamin pada ikan cakalng asap karena adanya pengurangan kadar air akibat dari pemanasan dan adanya senyawa-senyawa kimia dalam asap seperti golongan fenol yang dapat menghambat pertumbuhan mikroorganisme. Produk ikan asap yang diolah masih memenuhi standar mutu karena kadar histamin masih dibawah $100 \mathrm{mg} / 100 \mathrm{~g}$.

Tabel 1. Analisis Sidik Ragam Pengujian Histamin

\begin{tabular}{|c|c|c|c|c|c|}
\hline $\begin{array}{c}\text { Sumber } \\
\text { Keragaman }\end{array}$ & JK & DB & KT & $\mathrm{F}_{\text {Hitung }}$ & $\begin{array}{c}\text { FTabel } \\
0.05\end{array}$ \\
\hline Perlakuan & 405.34 & 3 & 135.11 & & \\
\hline Galat & 3724.42 & 8 & 465.55 & 0.29 & 4.07 \\
\hline Total & 4129.76 & 11 & & & \\
\hline
\end{tabular}

Tanin dapat menghambat pertumbuhan bakteri Staphylococcus aureus, Bacillussubtilis, dan Bacillus stearothermophilus melalui mekanisme pengubahan permeabilitas membran sitoplasma. Yuniarti (1991) menambahkan, tanin juga mampu menghambat pertumbuhan bakteri $E$. coli dan S. aureus.Oleh karena itu, tanin diduga dapat menghambat peningkatan histamin,karena histamin terbentuk dari hasil perombakan enzim dekarboxilase yang dihasilkan oleh bakteri.

Genisa (2000) berpendapat bahwa kandungan histamin pada ikan Scombroid yang sudah rendah mutunya berfariasi antara $10-100 \mathrm{mg} \%$, 
bahkan kadang-kadang sampai 1000 mg\%.Pembentukan histamin setiap spesies berbeda, tergantung padakandungan histidinnya, tipe dan banyaknya bakteri yang menunjangpertumbuhan dan reaksi mikroba. Pada daging ikan mekanismepembentukan histamin berupa autolisis maupun karena aktivitas mikroba. Akan tetapi kebanyakan hasil penelitian menyatakan bahwa histamin yang terbentuk sebagian besar berasal dari aktivitas mikroba.

Genisa (2000) tentang produksi histamin pada ikan Cakalang (Katsuwonus pelamis) selama lepas tangkap digunakan sebagai rujukan untuk menjadikan produksi histamin dapat dihambat dengan cara pemberian bahan pengawet alami dalam hal ini ekstrak daun belimbing wuluh pada ikan Cakalang (Katsuwonus pelamis) selama penyimpanan sebelum diolah lebih lanjut.

Senyawa histamin mungkin tak berbau busuk, tetapi keberadaannya dalam daging ikan menjadi berbahaya. Penggunaan bahan pengawet alami telah digunakan misalnya, arang yang telah digunakan oleh Ariyani et al.,(2006) untuk mengurangi histamin pindang ikan tongkol batik (Euthynnus affinis). Hasil penelitian ini menunjukkan bahwa penambahan arang dalam pengolahan ikan tuna asin rebus menurunkan kandungan histamin dari 140,5 mg/ $100 \mathrm{~g}$ (kontrol) menjadi 28,0 mg/100 g. Hasil analisis sidik ragam pengujian histamin dapat disajikan pada Tabel 1 .

Berdasarkan sidik ragam, nilai $\mathrm{F}_{\text {Hitung }}=0,29$ kecil dari $\mathrm{F}_{\text {Tabel }}$ pada taraf 5 $\%$ 4,07. Maka diputuskan bahwa ekstrak daun belimbing wuluh tidak berpengaruh nyata terhadap penurunan kadar histamine pada ikan cakalang asap.

\section{KESIMPULAN}

\section{Kesimpulan}

Kesimpulan yang dapat diperoleh dari hasil penelitian ini adalah konsentrasi ekstrak daun belimbing wuluh mampu menghambat peningkatan histamin ikan Cakalang (Katsuwonus pelamis) fufu. Hasil pengujian statistik penggunaan ekstrak daun belimbing wuluh tidak berpengaruh nyata terhadap kadar histamin ikan cakalang fufu (asap). 


\section{Saran}

Disarankan agar dilakukan Penelitian Lanjutan tentang konsentrasi ekstrak yang palin baik untuk digunakan sebagai bahan pengawet pada ikan cakalang (Katsuwonus pelamis) asap.

\section{DAFTAR PUSTAKA}

1. Ariyani, dan Faisal. 2006. Mutu Mikrobiologis Minuman Jajanan di Sekolah Dasar Wilayah Bogor Tengah. Jurnal Gizi dan Pangan 1 (1). hlm 44-50

2. Astuti, Metusalach, Genisa. J., 2015. Pemanfaatn Ektrak Daun Belimbing Wuluh untuk Menghambat Histamin dan Penurunan Mutu Ikan Cakalang (Katsuwonus pelamis L). Jurnal Aquabis 3(2): 29-34. Universitas Muhammadiyah Gorontalo.

3. Genisa, J. 2000. Produksi histamin pada ikan cakalang (Katsuwonus pelamis $L$ ) selama lepas tangkap. Desertasi, Pascasarjana UNHAS.

4. Kamilah, H.E., 2010. Dibalik mu'jizat tanaman belimbing wuluh (Averhoa billimbi. L) sebagai pengawet alami. Dosen jurusan Kimia, Fakultas Sains dan Teknologi UIN Maulanan Malik Ibrahim, Malang.

5. Ketaren, S., dan Suastawa, I.G.M., 1994. Pengaruh tingkat mutu buah panili (Vanilla planivolia A.) dan Nisbah Bahan dengan Pelarut Terhadap Rendemen dan Mutu Oleoresin yang dihasilkan. Fakultas Teknologi Pertanian, IPB

6. Kung, HF., Wang,TY., Huang, YR., Lin, CS., Wu, SW., Lin, CM., \& Tsai, YH. 2009. Isolation and identification of histamine-forming bacteria in tuna sandwiches. Journal of Food Control 20: 1013-1017.

7. Mukhliso. W., 2010. Pengaruh ekstrak tunggal dan gabungan daun belimbing wuluh (Averhoa billimbi.L) terhadap efektifitas anti bakteri secara invitro. Kimia, UIN Malan

8. Nento,WR., Nurhayati, T \& Suwandi, R. 2014. Quality changes of light flesh tuna at water of Tomini Bay, Gorontalo Province. JPHPI 17(3):225232

9. SNI 2345. 10: 2009. Cara uji kimia - Bagian 10: Penentuan kadar histamine dengan spektroflorometri dan kromatografi Cair Kinerja Tinggi (KCKT) pada produk perikanan. 
10. Sugeng Hadinoto, Joice P. M. Kolanus, Komers R. W. Dan Manduapessy, 2016. Karakteristik Mutu Ikan Cakalang (Katsuwonus pelamis) Asap Menggunakan Asap Cair Dari Tempurung Kelapa. Majalah BIAM. (01): 20-26.

11. Wibowo, S. 2000. Industri Pengasapan Ikan. Jakarta: Penebar Swadaya 